\title{
NESTING SITE SELECTION AND POPULATION NUMBERS OF THE BREEDING BIRD SPECIES IN HOYNAT ISLAND, TURKEY
}

\author{
GÜNDOĞDU, E.*-SARI, A. - ARPACIK, A. \\ Department of Wildlife Ecology and Management, Faculty of Forestry, Karadeniz Technical \\ University, 61080 Trabzon, Turkey \\ (phone: +90-505-934-3200) \\ *Corresponding author \\ e-mail: ebubekirgundogdu@gmail.com \\ (Received $22^{\text {nd }}$ May 2018; accepted $5^{\text {th }}$ Jul 2018)
}

\begin{abstract}
In this study, bird species of Hoynat Island, which is one of the two biggest islands on and around the Black Sea coast, and population trends of these species in a year and nesting site selection of breeding bird species, were examined. Hoynat Island is also the largest know area to show breeding behaviour for European shag in Turkey. Observations were conducted between 2011 and 2017 years. It was found three bird species preferred for nesting Hoynat Island throughout the year. These species are great cormorant (Phalacrocorax carbo Linnaeus 1758), European shag (Phalacrocorax aristotelis Linnaeus 1761) and yellow-legged gull (Larus michahellis J. F. Naumann 1840). These species show breeding and incubation behaviours on the island and surrounding rocks. While P. aristotelis uses the island as a short-term stopover when it first comes to the area, it stays in the rocks on the tunnel then and during the incubation process. $P$. carbo and L. michahellis do not use the rocks on the tunnel and only $P$. carbo stays for a while on the top of trees in the upper part of the tunnel. P. carbo and L. michahellis use the island as a stopover and incubation area. Using the island and surrounding as a nesting site, $P$. aristotelis, P. carbo and L. michahellis have reached the highest population in June. During this month, 170 P. aristotelis, 670 P. carbo and 475 L. michahellis were counted. It was found that breeding preparations of the birds in the study area started in February and hatching continues until June.
\end{abstract}

Keywords: habitat use, great cormorant, European shag, yellow-legged gull, Hoynat Island, Turkey

\section{Introduction}

Turkey is between two continents (Europe and Asia); therefore, it is a wealthy country in terms of fauna, flora and habitat diversity thanks to its location. Habitat loss and degradation on islands are key processes leading to population decline of birds. Habitat generalism is an important attribute in determining the ability to persist in heterogeneous and human-perturbed landscapes (Sol et al., 1997; Marvier, et al., 2004; Vergara and Armesto, 2009). Habitat generalist species have broad habitat amplitudes (occupying several habitat types) and usually they behave as opportunistic species, preferring the habitats offering more resources (Medel and Jaksic, 1988; Magura et al., 2003). Unlike specialist species, which are constrained to use a small habitat spectrum, habitat generalists may switch their habitat selection pattern over time as expected from habitat selection theory (Fretwell and Lucas, 1970; Rosenzweig, 1985; Latta and Faaborg, 2002; Chen et al., 2008). Consequently, changes in population size and in the spatial distribution of their resources over time may result in a wide temporal variability in habitat use by generalist species (Diamond, 1975; Holt, 1993; Mobæk et al., 2009; Hahn et al., 2011).

Great cormorant, European shag and yellow-legged gull are nested in Hoynat Island. In North America, great cormorants are strongly associated with marine coastlines, in contrast to their smaller cousins, double-crested cormorants. In Europe, great 
cormorants are also found in inland, freshwater areas and in coastal estuaries. Nesting habits may vary among subspecies. North American great cormorants (P. c. carbo) nest mainly along coasts. Eurasian subspecies $(P$. c . sinensis) nest in inland areas, but the two subspecies sometimes occur in nesting colonies together in areas of recent overlap (British Isles) (Hatch et al., 2000).

European shags are found throughout western Europe, from Iceland, the British Isles, Portugal, Gibraltar, and northern Africa east to Greece and north into the Ukraine and as far north as Norway. European shags are found along rocky, marine coastlines and islands and are never found very far from land or very far inland. Preferred foraging grounds are in clear, protected waters over sand or rocky substrates, such as in bays or coastal channels. They avoid fresh, brackish, or muddy water (Birdlife International, 2009; Del Hoyo et al., 1992). European shags build nests of sticks, seaweed, and other marine debris on rocky ledges, cliffs, or stacks. Nests have been found from just above the high water level to $100 \mathrm{~m}$ above the sea. Nesting areas host large concentrations of these birds, who nest in close proximity. Breeding season varies regionally, Black Sea populations breeding from January to March. (Del Hoyo et al., 1992; Snow, 2008; RSPB, 2009; Birdlife International, 2009; Arkive, 2018).

Yellow-legged Gull can be found in Europe, the Middle East and north Africa. It is resident in much of southern Europe, on the coasts of the Mediterranean, Black Sea and Caspian Sea, on the Azores and Madeira, Portugal, and on the Canary Islands, Spain. The nest is constructed of nearby vegetation, feathers, debris and old carcasses, and is preferably positioned close to or under bushes, or on rocky and sandy islands, beaches, spits, sea cliffs, grassy or shrubby river islands, and occasionally on high ground hundreds of meters from water (Del Hoyo et al., 2013).

Turkey, which is highly important for especially birds, hosts various bird species that are threatened with extinction worldwide. Hoynat Island is one of the 305 Key Biodiversity Areas (KBA) and 184 Important Bird Areas (IBA) of Turkey (Kılıç and Eken, 2004). The island is one of the two biggest islands of Black Sea. Hoynat Island is also the only area to show breeding behavior for European shag in Turkey. There is not any other comprehensive scientific study conducted for bird species in the study area. Only midwinter water bird count was observed during some years. But no data on the island has been revealed during these counts.

\section{Materials and methods}

\section{Study area}

Eastern Black Sea Region, where Hoynat Island is located, is situated in Caucasus which is one of the most important regions of the world in terms of nature conservation (Fig. 1). Caucasus Ecological Region, which is located between Black Sea and Caspian Sea and which covers lands of Azerbaijan, Armenia and Georgia and some parts of Russia, Iran and Turkey, is acknowledged as one of the wealthiest places of the world concerning biodiversity. Eastern Black Sea coasts located in this region host many bird species. The island is 100 meter away from the coast. There is not any settlement area on Hoynat Island. It is estimated that Hoynat Island was once used by sailors as a storage and shelter.

Hoynat (Akkuş) Island and its surroundings selected as study area in this project are located in Bolaman-Efirli route in Ordu province which constitutes the only natural coast line out of the highway influence area of $542 \mathrm{~km}$ Black Sea coast road completed 
in 2007. Therefore, this area is also one of the last natural habitats of the bird species in the Black Sea. There is not any other comprehensive study conducted for bird species in the study area. Depending on the observations carried out in different dates, Nature Association of Turkey identified Akkuş Island in the Eastern Black Sea as an Important Bird Area (IBA) (Kılıç and Eken, 2004). So, Akkuş Island IBA was registered as IBA with the code of DKD001-TR059 because of 'island under full protection and necessary to be monitored, area including important populations of bird species threatened with extinction' status, and the island located in $18 \mathrm{~km}$ west of Ordu and $100 \mathrm{~m}$ off the coast of land and region surrounded by high cliffs that are perpendicular to the sea are identified as 'necessary to be monitored' status. Under this study, Phalacrocorax aristotelis and Larus michahellis are the bird species determined in the area. Especially the island and its surroundings determined as breeding area of P. aristotelis which is threatened with extinction were acknowledged as important bird area with their natural and undisturbed structure. The project area was also identified as 'Culture and Tourism Protection and Development Region' by the Ministry of Culture and Tourism in 2009. Accordingly, Hoynat (Akkuş) Island was accepted by the Ministry of Culture and Tourism as an area necessary to be monitored under the categories of B1(i) and B3 with its 90 double $P$. aristotelis population in the Eastern Black Sea and Çoruh Basin.

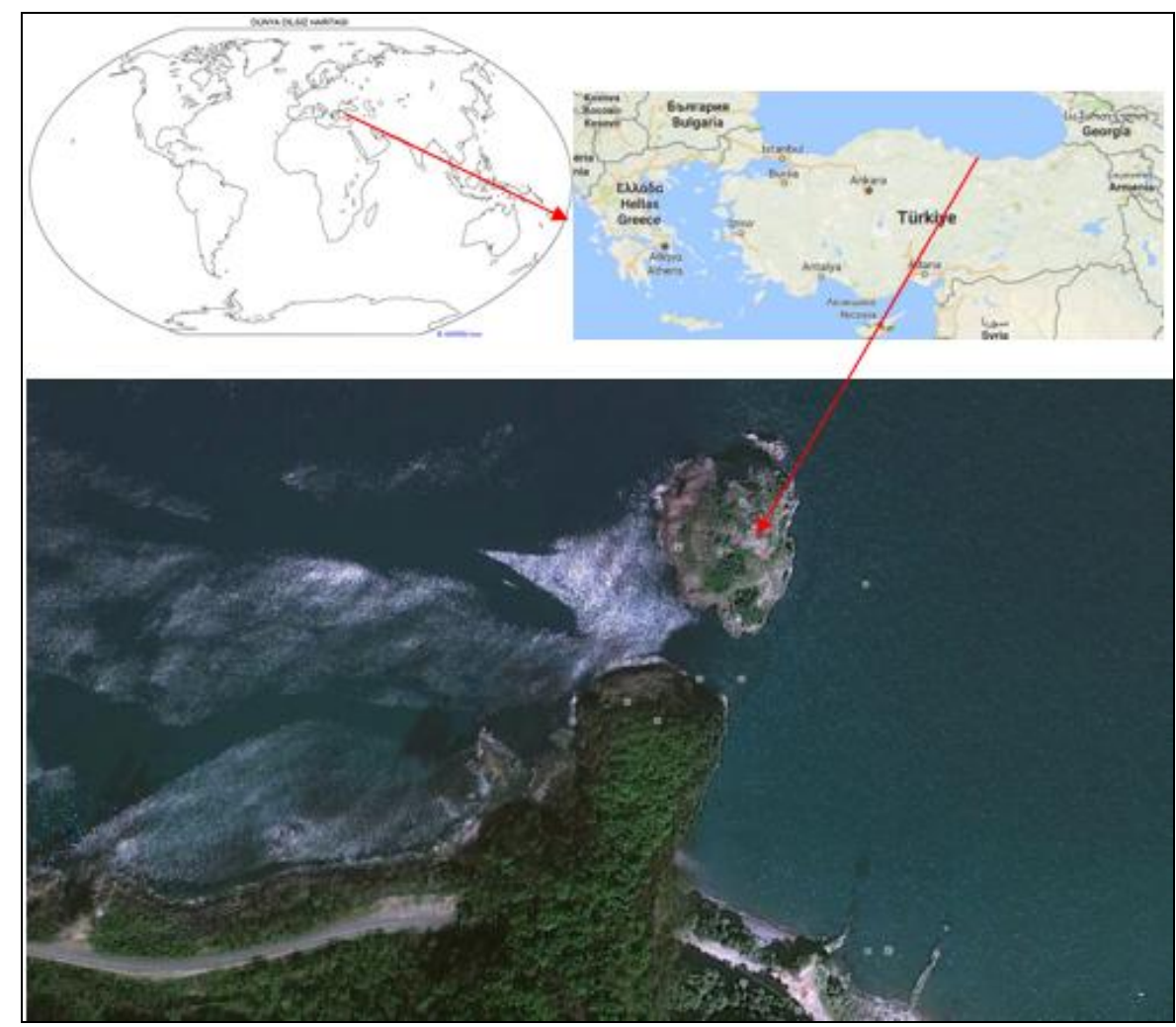

Figure 1. Location of study area (Google Earth)

\section{Bird sampling}

Direct observations were carried out to the study area every month periodically between June 2011 and January 2013 under the project (Bibby et al., 1992; Oğurlu, 2003). Observations continued from 2013 to 2017 after project during breeding seasons. 
Bird species which have high population spreading the area, habitat use and breeding situation of the species were tried to be identified by benefiting from Kiziroğlu (1989); Heinzel et al. (1992); Kasparek (1992); Jonsson (1993); Roselaar (1995); Kirwan et al. (1998) resources.

\section{Habitat classification}

We used the criteria of Hahn et al. $(2005,2010)$ as a guide for grouping vegetation units (hereafter called "habitat types"). This habitat classification is focused on habitat features important for birds, such as vegetation structure and dominant plant species, as well as geographical factors like altitude, exposition and incline. Three habitats, i.e. bushes on the island, meadows and tunnel bluffs, were classified as breeding habitats in the area.

\section{Results and discussion}

As a result of the studies carried out during the project, It was found three bird species preferred for nesting Hoynat Island throughout the year. These species are great cormorant, European shag and yellow-legged gull and showed breeding behaviours on the island and surrounding cliffs (Fig. 2; Table 1). Additionally, 1-3 individuals from Ardea cinerea, Egretta alba, Egretta garzetta, Larus canus, Larus ridibundus, Podiceps cristatus and Corvus corone species were also observed in Hoynat Island. Observations continued from 2013 to 2017 and no significant changes were observed in population numbers. Among these species, there is no endangered species on global scale. But Hoynat Island is the largest known area to show breeding behaviour for European shag in Turkey.

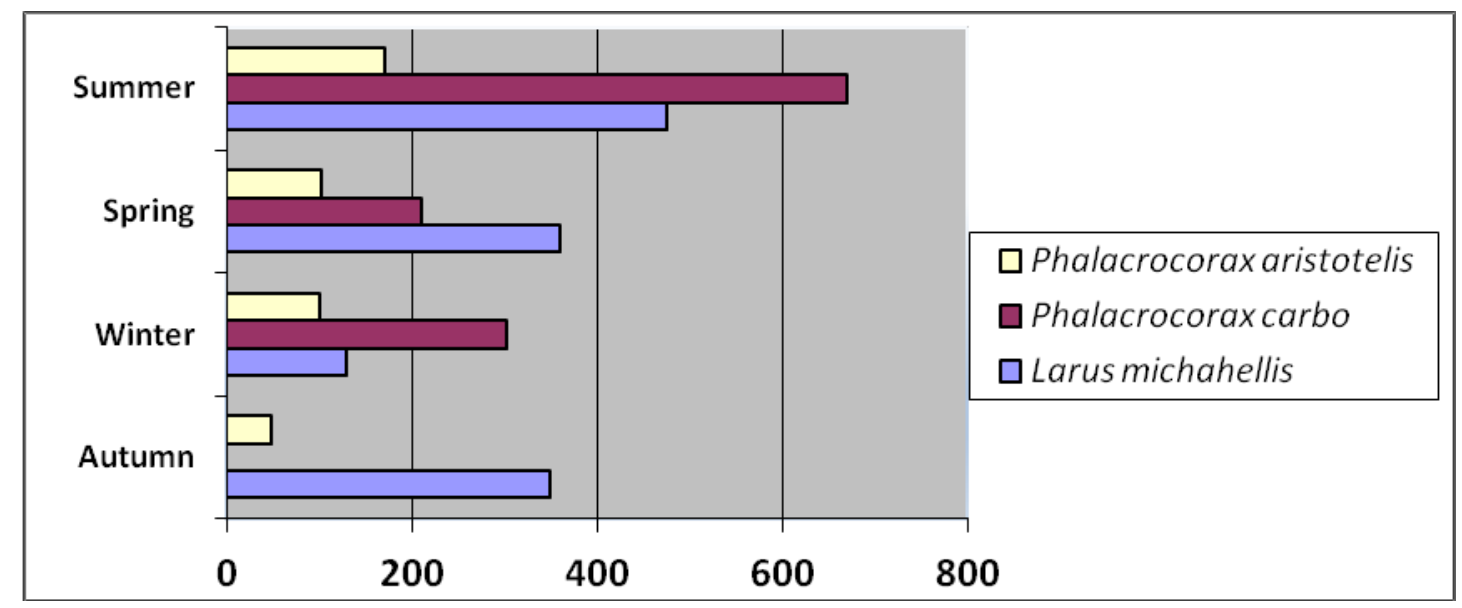

Figure 2. Seasonal numbers of the breeding bird species (P. aristotelis, $P$. carbo and $L$. michahellis) in Hoynat Island

It was found in the project area that breeding behaviors started in February and hatching continued until June. At the end of January, $P$. aristotelis and $P$. carbo started preparations for nesting at the end of February. Eggs started to open and hatching started in April. Therefore, P. aristotelis and P. carbo were observed as fully covered with their breeding coverage. On the other hand, L. michahellis incubated one month 
later and young birds exited from eggs around at the end of May or the beginning of June.

Table 1. The breeding bird species in the island and surrounding

\begin{tabular}{|c|c|c|c|c|c|}
\hline \multirow[b]{2}{*}{ Observation date } & \multirow[b]{2}{*}{ Species } & \multicolumn{3}{|c|}{ Habitat use } & \multirow[b]{2}{*}{$\begin{array}{c}\text { Total } \\
\text { number of } \\
\text { individuals }\end{array}$} \\
\hline & & $\begin{array}{l}\text { Rock balconies } \\
\text { on the tunnel }\end{array}$ & $\begin{array}{l}\text { Grassland } \\
\text { on the } \\
\text { island }\end{array}$ & $\begin{array}{l}\text { Bushland } \\
\text { on the } \\
\text { island }\end{array}$ & \\
\hline \multirow{3}{*}{6 June 2011} & Phalacrocorax aristotelis & 155 & & 15 & 170 \\
\hline & Phalacrocorax carbo & 25 & & 265 & 290 \\
\hline & Larus michahellis & 10 & 465 & & 475 \\
\hline \multirow{2}{*}{27 July 2011} & Phalacrocorax carbo & & & 25 & 25 \\
\hline & Larus michahellis & & 30 & & 30 \\
\hline \multirow{2}{*}{07 November 2011} & Phalacrocorax aristotelis & 23 & & & 23 \\
\hline & Larus michahellis & & 250 & 100 & 350 \\
\hline \multirow{3}{*}{29 January 2012} & Phalacrocorax aristotelis & 100 & & & 100 \\
\hline & Phalacrocorax carbo & & & 120 & 120 \\
\hline & Larus michahellis & & 30 & & 30 \\
\hline \multirow{3}{*}{30 March 2012} & Phalacrocorax aristotelis & 88 & & 15 & 103 \\
\hline & Phalacrocorax carbo & & & 210 & 210 \\
\hline & Larus michahellis & & 360 & & 360 \\
\hline \multirow{3}{*}{11 May 2012} & Phalacrocorax aristotelis & 70 & & & 70 \\
\hline & Phalacrocorax carbo & & & 185 & 185 \\
\hline & Larus michahellis & & 275 & & 275 \\
\hline \multirow{3}{*}{17 June 2012} & Phalacrocorax aristotelis & 97 & & & 97 \\
\hline & \begin{tabular}{|l|} 
Phalacrocorax carbo \\
\end{tabular} & & & 670 & 670 \\
\hline & Larus michahellis & & 450 & & 450 \\
\hline \multirow{2}{*}{14 July 2012} & Phalacrocorax carbo & & & 32 & 32 \\
\hline & Larus michahellis & & 47 & & 47 \\
\hline \multirow{2}{*}{15 August 2012} & Phalacrocorax carbo & & & 36 & 36 \\
\hline & Larus michahellis & & 42 & & 42 \\
\hline \multirow{2}{*}{28 October 2012} & Phalacrocorax aristotelis & 18 & & & 18 \\
\hline & Larus michahellis & & 225 & & 225 \\
\hline \multirow{2}{*}{30 November 2012} & Phalacrocorax aristotelis & 49 & & & 49 \\
\hline & Larus michahellis & & 320 & & 320 \\
\hline \multirow{3}{*}{04 February 2013} & Phalacrocorax aristotelis & 48 & & & 48 \\
\hline & Phalacrocorax carbo & & & 302 & 302 \\
\hline & Larus michahellis & & 130 & & 130 \\
\hline
\end{tabular}

During breeding period, bird species were found in the different habitat types. $P$. aristotelis used rock balconies on the tunnel, $P$. carbo used bushland and L. michahellis used grassland on the Hoynat Island. However, none of the species has interfered with each other's breeding areas during the breeding season (Table 2; Fig. 3). 
Table 2. Habitat types for breeding birds in Hoynat Island and surrounding

\begin{tabular}{|llc|}
\hline Bird species & $\begin{array}{l}\text { Habitat } \\
\text { types }\end{array}$ & Area $\left(\mathbf{m}^{2}\right)$ \\
Phalacrocorax aristotelis & Rocky area & 7565 \\
Phalacrocorax carbo & Grassland & 7294 \\
Larus michahellis & Bushland & 1840 \\
\hline
\end{tabular}

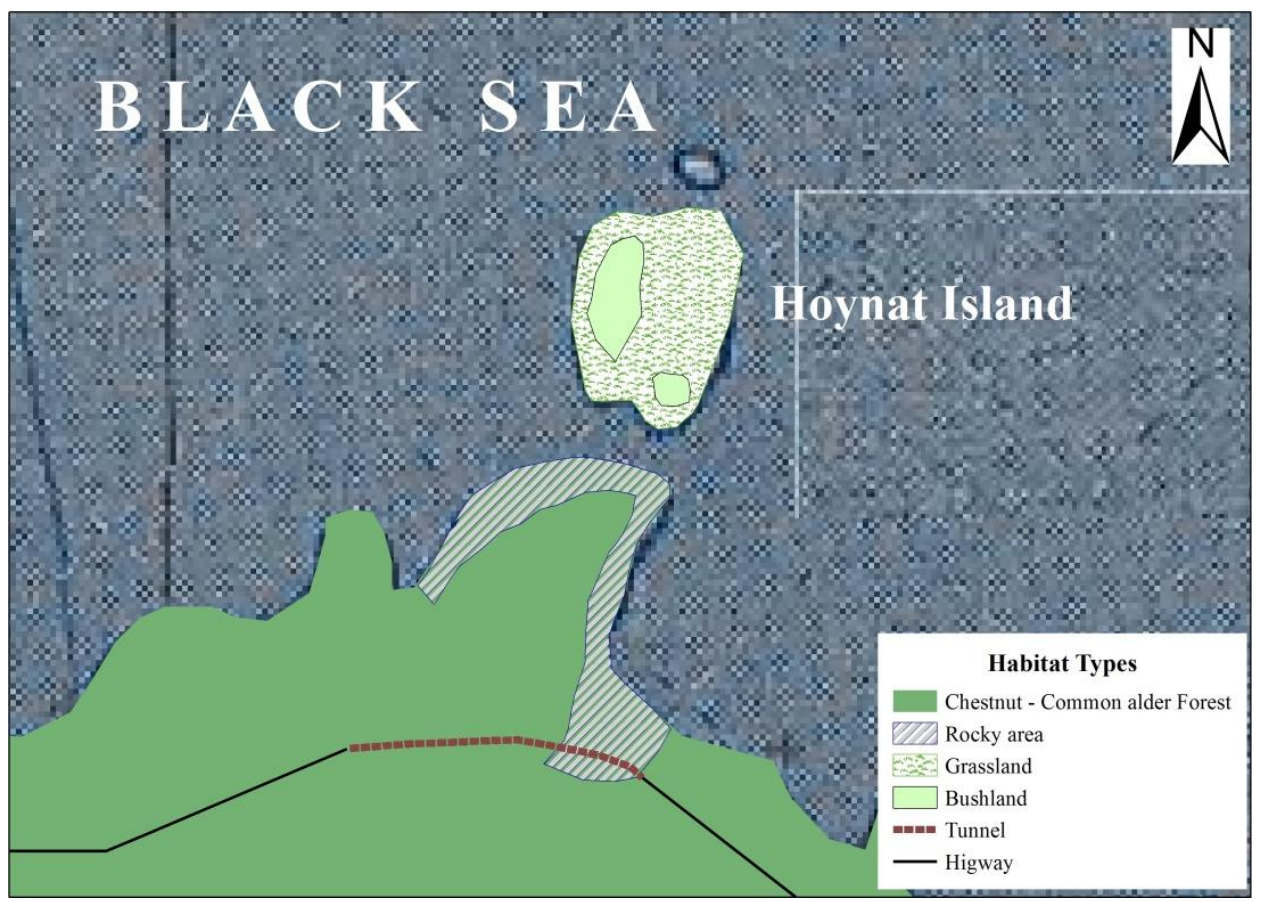

Figure 3. Habitat types for breeding birds in Hoynat Island and surrounding

It was also observed that there were differences between the nesting site selections of the identified bird species. Thus, rocks on the island and rocks on the tunnel were addressed as two habitats in terms of area usage of the birds. The island defines the area on which rocks, bushes and small trees exist and which does not have any connection with the land; on the other hand, rocks on the tunnel cover the top of the tunnel on the highway located in 200 meter of the island and cliffs located between tunnel and the island and including some balconies. While $P$. aristotelis uses the island as a short-term stopover when it first comes to the area, it stays in the rocks on the tunnel then and during the incubation process. $P$. carbo and L. michahellis do not use the rocks on the tunnel and only $P$. carbo stays for a while on the top of trees in the upper part of the tunnel. P. carbo and L. michahellis use the island as a stopover and incubation area. Using the island as a temporary stopover, A. cinerea never prefers the rocks on the tunnel (Fig. 4).

$P$. aristotelis makes a nest on the rock balconies on the tunnel and rock region near the tunnel by using brushwood; $P$. carbo makes a nest on the top of the bushes in the island or on the high grasses on the ground by using brushwood; L. michahellis makes a nest within the grasses in the island or on the ground and stone. In case of $P$. aristotelis and $P$. carbo 3-5 young birds hatch, whereas 2-3 young birds hatch in case of $L$. michahellis (Fig. 5). 


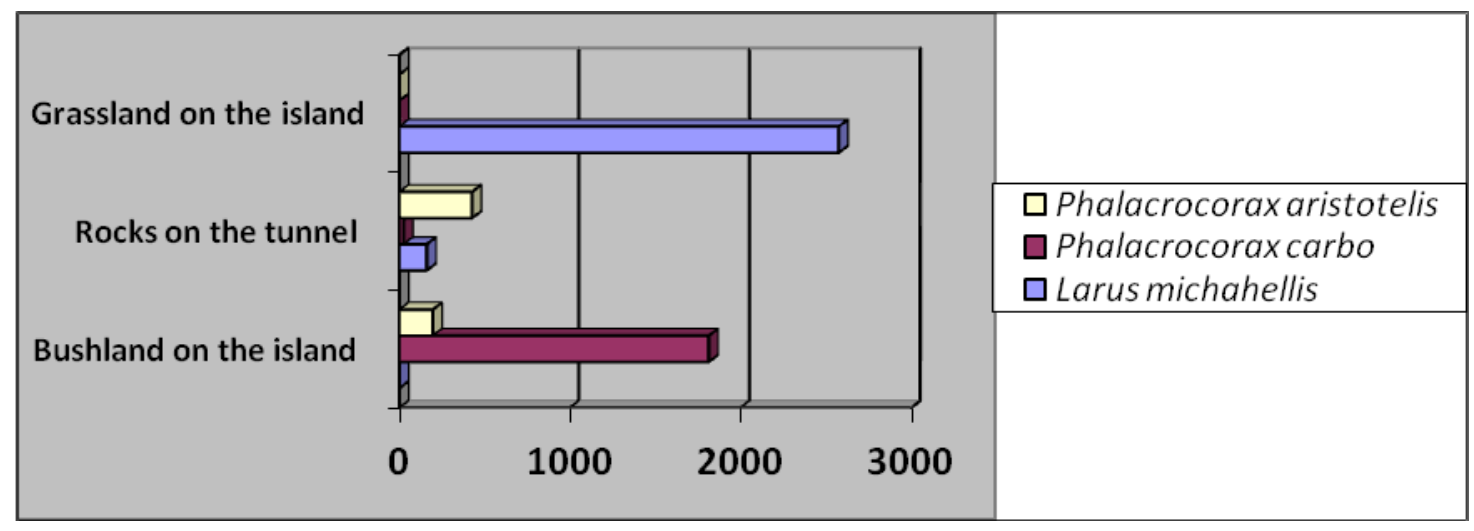

Figure 4. Nesting site selection of breeding birds in Hoynat Island and surrounding

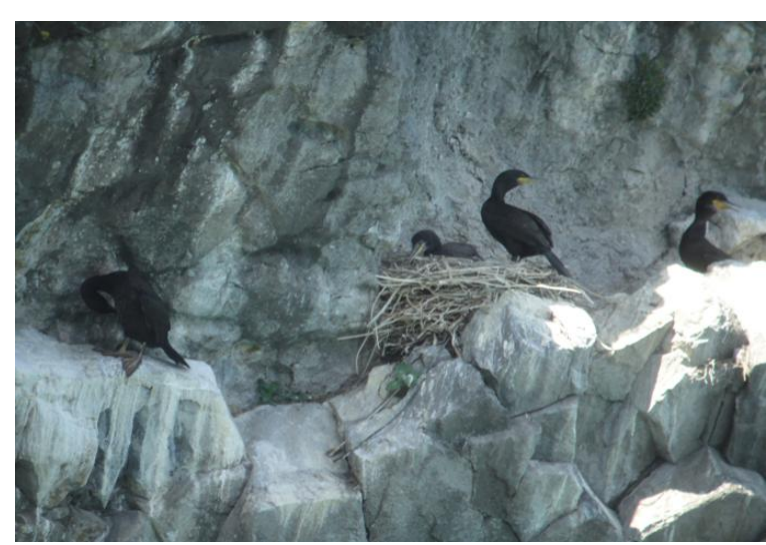

Phalacrocorax aristotelis

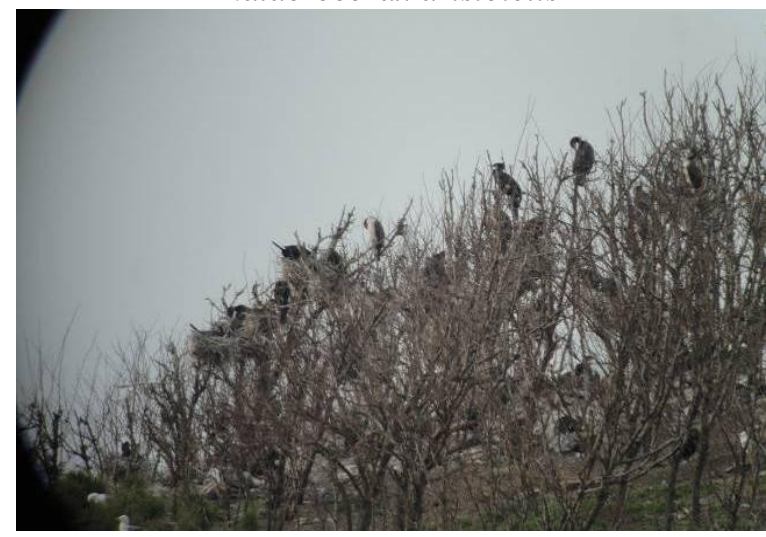

Phalacrocorax carbo

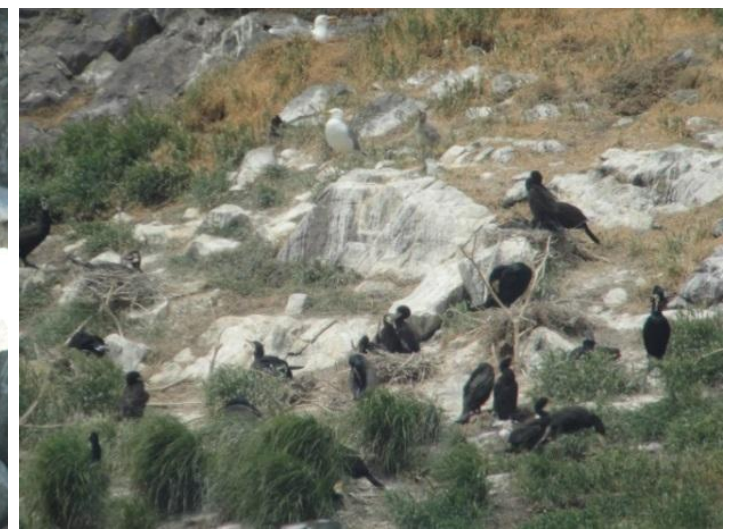

Phalocrocorax carbo

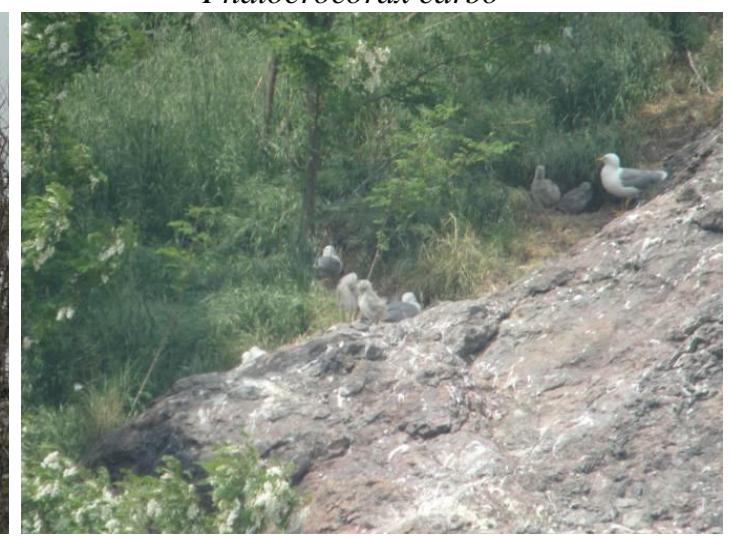

Larus michahellis

Figure 5. Nesting sites of the birds in Hoynat Island

Breeding habitat usage findings obtained in the study are consistent with the literature data. $P$. aristotelis prefers cliffs as nest; $P$. carbo prefers on the top of the bushes and L. michahellis prefers meadows. Therefore, rocks on the tunnel are also areas that should be protected as much as the island. That's why, it is recommended to give a 'Natural conservation area' status to the island and rocky area covering the area from the tunnel-top which is the most important area for $P$. aristotelis to the island in order to protect this area and hand down the next generations. 
Many different names are used for the area. For example, in the IBA book it is named as Akkuş Island; however, on the highway signs it is written as Hoynat Island. Local people use Hoynat Island and also Çaka Island. Therefore, it is important to use a single name for resources.

\section{Conclusions}

As a result of the studies carried out to date, the occurrences of three nesting bird species in Hoynat Island have been determined. Considering the number of bird populations observed in Hoynat Island, it can be seen how an important nesting area it is for the region and Turkey. Measurements must be taken against threat risks to protect the important bird nesting area. Further urbanization towards Hoynat Island must be stopped, and new buildings must not be allowed in this direction anymore. Study area is not within the scope of hunting ban. The field should immediately be registered into the hunting-ban areas.

Provincial Directorate of Culture and Tourism put a sign with the name of 'Hoynat Bird Paradise' in the project area and opened it ecotourism partly. However, no supportive activity has been implemented in the area. During the field work, many tourist groups who came to the island to make an observation during the summertime were encountered. So, it will be useful to build 'Birdwatching Terraces' in the appropriate places on the west and east exit of the tunnel across the island in order to attract attention and facilitate birdwatching. Hoynat Island should be closed to national and international tourism activities during breeding seasons.

Construction work should not be conducted between February - June which are the breeding months of the birds, and rocks on the tunnel and near the tunnel should not be damaged during the work.

Acknowledgements. This research supported by the Scientific Research Projects Commission of Karadeniz Technical University (project no: BAP03/1100) is fully acknowledged.

\section{REFERENCES}

[1] Arkive (2018): "Phalacrocorax aristotelis". - http://www.arkive.org/shag/ phalacrocorax-aristotelis (accessed on 28 April 2018).

[2] Bibby, C. J., Burgess, N. D., Hill, D. A. (1992): Bird Census Techniques. - Academic Press, London.

[3] Birdlife International (2009): "Phalacrocorax carbo". - http://www.birdlife.org 28 (accessed on May 2018).

[4] Chen, J., Wang, X. M., Zhang, S. Y. (2008): Dietary shifts in relation to fruit availability among masked palm civets (Paguma larvata) in central China. - J Mammal 89: 435-447.

[5] Del Hoyo, J., Elliott, A., Sargatal, J. (1992): Handbook of the Birds of the World, Volume I. - Lynx Edicions, Barcelona.

[6] Del Hoyo, J., Elliott, A., Christie, D. A. (2013): Handbook of the Birds of the World. Special Volume: New Species and Global. - Lynx Edicions, Barcelona.

[7] Diamond, J., Cody, M. (1975): Ecology and Evolution of Communities. - Belknap Press, Cambridge, pp 342-444. 
[8] Fretwell, S. D., Lucas, H. L. (1970): On territorial behavior and other factors influencing habitat distribution in birds-I. Theoretical development. - Acta Biotheor 19: 16-36.

[9] Hahn, I., Römer, U., Schlatter, R. (2005): Distribution, habitat use, and abundance patterns of land bird communities on the Juan Fernández Islands, Chile. - Ornitol Neotrop 16: 371-385.

[10] Hahn, I., Vergara, P., Römer, U. (2010): Forest structures of the Juan Ferna'ndez Islands, Chile: significance for bird community composition and conservation. - GeoOeko 31: 1-10.

[11] Hahn, I., Vergara, P. M., Römer, U. (2011): Habitat selection and population trends in terrestrial bird species of Robinson Crusoe Island: Habitat generalists versus forest specialists. - Biodiversity and Conservation 20(12): 2797-2813.

[12] Hatch, J., Brown, K., Hogan, G., Morris, R. (2000): Great Cormorant (Phalacrocorax carbo). - The Birds of North America Online 553: 1-20.

[13] Heinzel, H., Fitter, R., Parslow, J. (1992): Birds of Britain and Europe with North Africa and the Middle East. - Collins, London.

[14] Holt, R. D. (1993): Ecology at the Mesoscale: The Influence of Regional Processes on Local Communities. - In: Ricklefs, R., Schluter, D. (eds) Species Diversity in Ecological Communities. University of Chicago Press, Chicago, pp. 77-88.

[15] Jonsson, L. (1993): Birds of Europe with North Africa and the Middle East. - Princeton University Press, New Jersey.

[16] Kasparek, M. (1992): Die Vögel der Türkei. First edition. - Max Kasparek Verlag, Heidelberg, Germany.

[17] Kilıç, D. T., Eken, G. (2004): Turkey's Important Bird Areas. - Nature Society, Ankara.

[18] Kirwan, G. M., Martins, R. P., Eken, G., Davidson, P. (1998): A Checklist of the Birds of Turkey. - Supplement 1. Ornithological Society of the Middle East, Sandgrouse.

[19] Kiziroğlu, İ. (1989): Birds of Turkey. - I. Press, General Directorate of Forestry, Presidency of Education Department, Directorate of Publication and Promotion Branch, Ankara.

[20] Latta, S. C., Faaborg, J. (2002): Demographic and population responses of Cape May warblers wintering in multiple habitats. - Ecology 83: 2502-2515.

[21] Magura, T., Bela, T., Elek, Z. (2003): Diversity and composition of carabids during a forestry cycle. - Biodivers Conserv 12: 73-85.

[22] Marvier, M., Kareiva, P., Neubert, M. G. (2004): Habitat destruction, fragmentation, and disturbance promote invasion by habitat generalists in a multispecies metapopulation. - Risk Anal 24: 869-878.

[23] Medel, R. G., Jaksic, F. M. (1988): Ecologi'a de los Ca 'nidos sudamericanos: una revisio 'n. - Rev Chil Hist Nat 61: 67-79.

[24] Mobæk, R., Mysterud, A. L., Loe, E., Holand, Ø., Austrheim, G. (2009): Density dependence and temporal variability in habitat selection by a large herbivore: an experimental approach. - Oikos 118: 209-218.

[25] Oğurlu, İ. (2003): Wildlife Census. - T. C. Ministry of Environment and Forestry, General Directorate of Nature Conservation and National Parks, Presidency of Hunting and Wildlife Department, Ankara.

[26] Roselaar, C. S. (1995): Songbirds of Turkey (Taxonomy-morphology-distribution). An Atlas of Biodiversity of Turkish Passerine Birds. - Pica Press, Haarlem, Netherlands and East Sussex, UK.

[27] Rosenzweig, L. M. (1985): Some theoretical aspects of habitat selection. - In: Cody M (ed) Habitat selection in birds. Academic Press, New York, pp. 517-540.

[28] RSPB (2009): "Shag". - Royal Society for the Protection of Birds. http://www.rspb.org.uk/wildlife/birdguide/name/s/shag/index.asp (accessed on 10 July 2010. 
[29] Snow, B. (2008): The breeding biology of the shag Phalacrocorax Aristotelis on the Island of Lundy, Bristol Channel. - Ibis 102: 554-575.

[30] Sol, D., Santos, M. D. E., Feria, E., Clavell, J. (1997): Habitat selection by the Monk Parakeet during colonization of a new area in Spain. - Condor 99: 39-46.

[31] Vergara, P. M., Armesto, J. J. (2009): Responses of Chilean forest birds to anthropogenic habitat fragmentation across spatial scales. - Landsc Ecol 24: 25-38. 